\title{
Local wisdom of Bali as a foundation to strengthen the nation's character building
}

\author{
I Wayan Kertih \\ Civic Education \\ Ganesha University of Education \\ Bali, Indonesia \\ iwayankertih@gmail.com
}

\begin{abstract}
The practice of our character education in schools generally was just only based on the teaching of subject matters. The consequence was that the students were able to understand the subjects but their behaviors were still far from good conducts. That is why teachers of SMPN 1 Singaraja practice some local values of Bali as a foundation to strengthen good conduct of their students. This study was aimed at explaining practices of Bali character values done through school education and civic education at SMP N 1 Singaraja. This study used educational ethnographic research design and involved school committee, school principal, community leaders, teachers, and students as the informants. Data were collected by doing observation, interview, and studying documents. Data were then analyzed by domain analysis, taxonomic analysis, componential analysis, and discovering cultural themes. The results showed that (1) Local wisdom of Balinese people can be used as a foundation to strengthen the implementation of educational program oriented to the development of the nation's character values; (2) Civic education has a strategic role in character education of the nation; and (3) The nation's character education is strengthened by of Bali community local wisdom values-based is believed to be capable of producing Balinese young generation with Indonesian character. The implication of this study was that schools in Bali necessarily use some local values.
\end{abstract}

Keywords-civic education local wisdom; national character building

\section{INTRODUCTION}

National character education is naturally an empowering, humanizing and civilizing process of the students' potential. Character education is also a civilization process. In these processes education helps to develop knowledge, values, belief system, norms, traditions or habits, rules skills which are coherent and useful for the individuals, schools, families and community, and even the nation.

Civic education as the integral part in educational curriculum at school, of course, is also responsible for conducting character education in an effort to advance a dignified Indonesian nation civilization and for the integrity of the unitary state of the republic of Indonesia. To achieve this objective, civic education has to become an integrative study that can empower all the potential of the students to make them have the capability to overcome problems in human life in various dimensions of space time, activity, and values in the environment [1]. By its nature as an integrative study of social science, humanity, religion, and culture civic education has to be able to bring the students to reach truths, and also happiness in life, to produce good citizens who have strong knowledge, and are able to lead a meaningful life [2].

The problem is civic education at school so far has been oriented toward the mastery of certain materials which cannot enable the teacher to integrate character education and national character education mission optimally. There are two constraints faced by the teacher at school, especially in civic education. First, the school curriculum, especially for civic education, in developing the concept of nation and character building, is dominated by the concept of nationalism of the nation [3]. Secondly, civic education makes it difficult for the teacher to integrate the mission of character education and the national cultural values. This is because the scientific values that are the basis for civic education which are oriented toward the mastery of scientific materials in the study area also tends to be singular and has less respect for pluralistic and multicultural community which is really alive in the midst of students' environment.

To be able to integrate character education and national cultural values into civic education at school, there is a need to reconstruct policies and practice implementation of civic education at school. In relation to this effort, one needs to start from the construction of input context (policies and school social environment), educational process, and the students' achievement in civic education. This is actually the main reason for conducting this study.

\section{THEORETICAL}

Bali has many values of local wisdom, among which the best known and used as the foundation in the life of the community is "Tri Hita Karana". In terminology, the concept of "Tri Hita Karana" comes from the word "tri", meaning three; "hita" means prosperous, happy; and "karana", meaning cause. So, "Tri Hita Karana" means three sources of welfare and happiness in the life and life of all divine beings [4].

In relation to the community local culture, the wisdom values that need to be developed in the context of the occurrence of changes in the globalization era, and are believed 
to have the capacity for strengthening national character values of the students were revealed.

First and foremost is the importance of maintaining values, attitudes, and religious practices. Religion was believed to serve a function not only as the controller of human attitude and behavior, but as the foundation of motivation, the strengthener of identity and the orienteer of actions to reach the objective of community life. Secondly, is familiar values, togetherness that have the cores of ideal values of polongan (humanity) by developing harmonious social relations among individuals, family members, and among families, among community members with the principles of suka-duka, paras paros sarpanaya, segilik seguluk selunglung sebayantaka, and saling asah, saling asih, saling asuh as the foundation in developing a harmonious large community relation. The value that underlies these principles is the teaching about tat twam asi. Thirdly, there is a need to apply the concepts of "menyama braya" and "Tri Kaya Parisudha", as the foundation in regulating interactions in the school community and developing tolerance, responsibility, and harmony in the life in the school community that is increasingly more heterogeneous and is oriented toward multicultural life.

Fourth, there is a unity and harmony between human beings and the nature since actually human being and nature are one. Fifth, there are ethic and aesthetic values in the life of art among Balinese. In this case, the ethical and esthetical values in Balinese life as artists. In this case, Balinese, in general, tends to appreciate a balance in reaching material and spiritual or the balance in material and spiritual wellbeing or sekala and niskala. In doing an activity, work has to contain values such as: metaksu, nyalanang jengah, and the spirit of puputan. All of the values above in principle are the elaboration of the values of "Tri Hitam Karana" that form the central values (core values) that form the foundation for Balinese in relating to the creator, his or her fellow human being, and the natural environment.

For Balinese the ideal values as shown above need to be inherited from one generation to the next for preserving Balinese community and culture. It is these values that need to be taught to the students as the foundation for strengthening the development of the 18 national character values, which are: "religious, honest, tolerant, disciplined, hard working, creative,, democratic, curious,, having national spirit, love homeland, appreciate achievement, communicative, love peace, diligent, take care of the environment, and have a great responsibility" Here we can see a uniqueness that SMP Negeri 1 Singaraja has in implementing its educational program. In relation to the implementation of cultural and national character education such uniqueness will make it more probable to create an educational climate with a multicultural nuance.

\section{METHOD}

In accordance with the problems and aims of this study, it used educational ethnography design. The use of educational ethnography design was based on the rationale that the focus of this study was to describe and to give a detailed account about cultural phenomena that can be reconstructed according to the perspective of participants in this study naturally in relation to a unity of systems in the form of programs, activities, events [5].

Based on the characteristic of the problem, this study focused more on an investigation into activities of the subjects of the study in doing activities in accordance with the problems being studied. For this purpose, the researcher tried to be always close to, among, or together with the subjects of the study. In this study, the researcher became the main instrument in order to collect data as authentically as possible. The researcher was directly in the field to do participatory observations, in-depth interviews, discussions and to study the existing documents. To be able to play such roles, the procedures of study followed the working principles of qualitative research.

All of the data were collected through documents study, observation activities, in-depth interviews, and through participation the researcher was intensively involved in the school activities during the study. This study followed the principle of "human instrument", that is, the researcher was the one who dug/ the main instrument. In accordance with the types of data collected above, in this study there were some major methods/ techniques of data collection, including (1) observation method, (2) interview, (3) document study, and (4) discussion. The process of data analysis in this study was done simultaneously and cyclically using the process of data collection often called interactive cyclical data analysis. The technique of data analysis, therefore, was done qualitatively. All of the data were analyzed by doing various activities that comprise: (1) data reduction, (2) data display, (3) data interpretation, (4) data verification, and (5) conclusion drawing [6].

In this section, a detailed and systematic description of the results of the study and the discussion in accordance with the focus of the problems are given as follows.

\section{RESUlt AND DisCUSSION}

Related to the conditioning / civilizing of cultural values and national characters that is done at SMP Negeri 1 Singaraja, this study found that the school has made some efforts, including:

\section{A. Civilizing character values through setting up school and classroom environments}

In relation to creating a character educational climate that is done through setting up school and classroom environments, the setting up of the physical environment is done based on the principle of Tri Mandala. This shows that the effort of the school to create the educational climate to achieve the school vision: unggul, berbudaya, dan berorientasi global.

\section{B. Civilizing national character values through curriculum integration}

In relation to integrating cultural values and national character in the curriculum, the policy followed is by integrating the 18 character values into 10 (ten) compulsory subjects offered at SMP Negeri 1 Singaraja. In this case, the 
school does not provide a special subject in the school curriculum for character education, and in the teaching of each subject there is not a special topic that discusses materials about character education, but it is integrated in every subject.

\section{Cultural and character education through Civic education}

In relation to civic education at SMP Negeri 1 Singaraja, this study found out that civic education as a subject taught at the school plays a strategic role in the implementation of cultural and national character education. In the school principal's perspective, civic education has the same position as other subjects in the implementation of cultural and national character education at SMP Negeri 1 Singaraja.

In civic education teaching, it appears that the teachers have made great efforts to integrate national character values into every basic competence (KD) in the teaching programs that they develop. Unfortunately, in the implementation of the teaching it cannot be optimally achieved. Out of all processes that have been followed in civic education, this study found out that civic education that the teachers conducted has not yet reflected its form as a cultural and national character education. Although the teachers have been able to integrate character values in their teaching programs (syllabus and lesson plans), in its implementation it did not significantly apparent, even it tended to be ignored, both in the materials development and assessment.

In relation to the materials development, the weakness in the process of explaining social interaction, for example, is that it does not only teach concepts and facts, but it also has to explain values behind the historical facts. As a cultural and national character education, civic education has to be able to develop cultural and national values in the students. In this way, it has to be formulated clearly in the teaching objectives [7-9]. There is a fundamental weakness in civic education, especially in planning, in which the teachers see the integration of cultural and character education only as a nurturing effect of civic education. It is such perspective that makes the teachers then fail to formulate it in the lesson plan as the objective of the teaching that forms a competence that should be acquired by the students.

In terms of values and moral education missions, civic education as far as the curriculum is concerned, as mentioned above cannot develop an autonomous reasoning ability in values and morality in the students. This is not only because of the fact that the students are never empowered in the ability to develop values and moral reasoning and the ability to make value loaded decisions in rational and autonomous way, but also because of the fact that value massages taught by the teachers through value information giving system tend to make the students bound by the traditions, the system of norms, and the existing values in the society that are considered to be established [10]. The fact is that such teaching has caused many value conflicts in the students. This is certainly caused by the fact that in reality in the society, many value and norm systems are violated by the community members themselves. Finally, from the point of social skills that should have been developed in civic education program in the curriculum, the reality shows that the students feel that they are poor in experiences in developing social skills that are useful in the life of the community and nation [11]. This is also less than optimally done in the teachers' efforts to empower important elements in the life of the community, and the use of symbols as media and learning resources in civic education. On the contrary, various important elements in the life of the community are available at schools and the surroundings that can be used as media for character values conditioning and in training the students' social skills.

In relation to the teaching, it seems that it has not shown the application of teaching principles that encourage the students to recognize and accept cultural values and national character as their values and character, and to be responsible for decisions that they make through the stages of recognizing options, assessing options, and then deciding positions and making values to fit their beliefs. The teaching developed has not yet shown an effort to make the students learn through the processes of thinking, behaving, and acting. The three processes have not been apparent in what the teachers have done. In the context of cultural and national character education, these processes are important to be followed to develop the students' ability in doing social activities and in encouraging them to see themselves as social beings $[12,1]$.

From the substance of attitude and cultural values development, the condition of ideological hegemoni al condition of the national culture that is intervened through the national education system, civic education as if had also caused the students to be uprooted from their local cultures. In the meantime, their attitudes and nationalist values orientation have not been strongly internalized. Not only has this caused the weakening of local social literacy in the students, but it has also weakened the students' commitment, attitude, value orientation and competence in appreciating and developing local products and cultural values. It is suspected to be caused by civic education at school that certainly does not create enough student interactions with the local products and cultural values. Such teaching practice is certainly not suitable with the nature of civic education education, that is in principle, has the mission as civics education, social science education, inquiry and reflective education, an integrative teaching, and social participation education. As civics education, civic education has to be able to develop the citizens' ability to become good citizens in the life of the democratic community based on the 1945 Constitution that is characterized by the ability to make decisions smartly and rationally and to participate in policy making and implementation at the local, national and global levels [13-15].

It is here that it is important to reconstruct understandings in the practice of civic education to make civic education be able to play the role as cultural and national character education. In this case, civic education has to be able to develop the students' competence to actively solve social problems that are faced by the society through cross-, multiand interdisciplinary approach. As cultural and national character education, all traditions in civic education program have to be implemented in an integrative, holistic, sustainable and meaningful manner. Civic education has to be able to develop the students' competence to be able to participate 
socially in the life of the community in various levels in understanding and criticizing the existing social problems, in solving problems and making decisions, in developing and proposing policy alternatives, in making action plans, and in implementing actions in accordance with the level of development and contribution that can be made to the society.

With such understanding as above, civic education as a program for teaching the social science basic concepts in as far as the curriculum is concerned with the hegemony of national cultural values is very important, but it is far more important to facilitate the students in developing and using knowledge, values and attitudes and life skills (personal, social, academically intellectual and vocational) to be able to participate in the life of the community in preserving, and developing culture at local, national and global levels. In this way, the limitations of civic education program in the curriculum and the limitations of the teachers as civic education teachers in achieving the objectives of civic education can be reduced. By reconstructing the understanding of knowledge and social learning as mentioned above, the teachers and students must believe that to learn civic education it is not enough to limit their activities to what is written in the curriculum guidelines with its curricular activities that are formally done at school, which are exactly known to have substantial weaknesses both in terms of the school effort to empower the community and local culture and to optimize the learning process that can empower the students. The civic education curriculum has to cover all the resources that can be managed and actualized by the school in the effort to empower the students to achieve the learning objectives of civic education, that cover the development of knowledge, values and attitudes and social skill; the development of personal, social, intellectual, academic, and vocational dimensions; the integration in developing a learning climate with sociocultural context that is integrated with curricular, curricular and extracurricular activities and participative learning in the relationship between the school and the community; the integration of learning theoretically and social practically; the integration in interpreting learning as the process of learning how to know, how to do, how to be, and how to live together; and the integration in appreciating local, national, and global cultural value contents. When we relate this to the powerful characteristic of civic education, such integration is at least expected to be able to improve meaningfulness, integration, challenge, value base, and active characteristics of civic education program at school.

From the explanation about the above framework, it is clear that it can be understood that the philosophical foundation that can be used as the basis for the teachers to develop civic education program at school is not only that of the essentialism of education as such but also a more progressive framework. In this more progressive perspective, civic education is a process that grows and develops by reconstructing social life experiences. Such kind of civic education is not an effort to prepare children for an adult life, but as a dynamic process of social life. This is only done in the condition of social life of the community that is democratic that makes it possible for each person to participate and to be involved actively in the life of the community that continuously undergoes transformational process.

Civic education has to prepare children to be active in the learning process that reflects the democratic community social structure to lead the students to change their behaviors. In this light, civic education program has to provide an educational curriculum which is rooted in the students' and the community needs and makes use of the application of intelligence to solve human problems and community problems. The kind of learning that is relevant to such curriculum above is the one that actively involves the role of the students in the participative learning process, cooperative work, learning by doing, and inquiry process [16-18].

Civic education also needs to integrate environmental, mental, social, moral and spiritual activities at the same time. It is such teaching that is actually suitable with the objectives of the implementation of cultural and national character educational program. In keeping with this, there is a need for selecting and developing various learning resources and learning/ teaching media that will enable the happening of learning process that can generate all of the potentials of the students (intellectual, social, and emotional). To reach this objective, the students are required not only to rely on himself or herself in facing what happens in the classroom, but he or she also has to want to and be able to trace and use a variety of learning resources needed. Various important elements in the life of the community in the form of the community local wisdoms can be be used as learning resources and teaching media [19].

\section{CONCLUSION}

This study produced a number of findings as follows

Tri Hitam Karana, Tri Kaya Parisudha, Tatwamasi, Asah Asih Asuh, Segilik Seguluk, Menyama Braya, Nyalanang Jengah, Kerja Metaksu, are Bali community local wisdoms that need to be preserved and transformed into a foundation to strengthen national character values.

The creation of school educational climate and civic education that is based on local wisdom values can be used as media in civilizing national character values to develop modern Balinese young generation with Indonesian national character

Civic education as the means for cultural and national character education should be interpreted as the process of student's empowerment that enables them to develop knowledge and insights, values and attitudes, as well as social skill through participations in the teaching of sociocultural life of the community.

The findings of this study have a theoretical implication that civic education at school needs to be developed by using social reconstruction approach in order the students have the ability to think globally, act locally, and respect the nationalism. Thus, civic education as a means to educate national character needs to be treated and developed in the perspective of local culture, without ignoring the commitment to the national life, and the development of global thinking ability. 


\section{REFERENCES}

[1] S.H. Hasan, Inovasi Pembelajaran IPS dalam Membangun Karakter Peserta Didik, FPIPS-UPI Bandung, 2010.

[2] M.N. Somantri, Menggagas Pembaharuan Pendidikan IPS Bandung: PT Remaja Rosdakarya 2001.

[3] I.G. Widja, Pelestarian Budaya: Makna dan Implikasinya dalam proses Regenerasi Bangsa in T.R. Sudhartha, et al. (ed), Kebudayaan dan Kepribadian Bangsa, Denpasar: Upada Sastra pp. 45 - 63.

[4] I.G.K. Kaler, "Butir-butir tercecer tentang adat Bali," vol. 2, Bali Agung, 1983

[5] C. Combleth, Research on Context, Research in Context. Dalam J.P. Shaver (Ed.). Handbook of Research on Social Studies Teaching and Learning: A Project of the National Council for the Social Studies. New York: Macmillan Publishing Company. 265-275, 1991.

[6] M.B. Miles and A.M. Huberman, Analisis Data Kualitatif: Buku Sumber tentang Metode-metode Baru, Tjetjep Rohendi Rohidi (translator), Jakarta: UI Press, 1992.

[7] M. Bunyamin, Bunga Rampai Pendidikan Umum dan Pendidikan Nilai, CV. Yasindo Multi Aspek: Bandung, 2009.

[8] R. Kevin and B. Kahlen, Building Character in School. John Wiley and Sons, Inc: San Francisco, 1999.

[9] S. Pasandaran, Integrasi Pendidikan Karakter ke dalam Kurikulum Sekolah (Seminar Nasional dan Forum Pimpinan FIS, FISE, FPIPS, JPIPS se Indonesia 19 November 2010), Menado, 2010.
[10] J.R. Coombs, Objectives of Value Analysis, in Lawrence E, Metcalf (Ed.), Values Education:Rationale Strategies and Procedures 41st, Washington DC: Yearbook, NCSS, pp. 1-28, 2010.

[11] P.H. Martorella, Elementary Social Studies: Developing Reflective, Competent, and Concerned Citizens. Boston, Toronto: Little, Brown and Company, 1986.

[12] Kemendiknas RI, Pengembangan Pendidikan Budaya dan Karakter Bangsa; Bahan Pelatihan Penguatan Metodologi Pembelajaran Berdasarkan Nilai-Nilai Budaya untuk membentuk Daya Saing dan Karakter Bangsa. Jakarta: Badan Penelitian dan Pengembangan Pusat Kurikulum Kemendiknas, 2010.

[13] J.A. Banks, Teaching Strategies for the Social Studies, (4th ed.), New York \& London: Longman, 19811990.

[14] R.D. Barr, J.L. Barth, and S.S. Shermis, The Nature Sosial Studies, Palm Spring: An ETS Pablication, 1978.

[15] U.S. Winataputra, Peran Pendidikan Ilmu Perngetahuan Sosial (PIPS) dalam Konteks Pembangunan Karakter Bangsa; Kebijakan, Konsep, dan Implementasi, 2010.

[16] P.F. Oliva, Developing the Curriculum. 3rd Edition, New York: Harper Collins Publishers, Inc, 1992.

[17] W.F. O'neil, Ideologi-ideologi Pendidikan, O.I. Naomi (translator), Yogyakarta: Pustaka Pelajar, 2001.

[18] R.D. Van Scotter, Social Foundations of Education. Second Edition. Englewood Cliffs, New jersey: Prentice-Hall, Inc, 1985.

[19] G.M. Schuncke, Elementary Social Studies; Knowing, Doing, Caring, USA: MacMillan Pub.Co, 1988. 